\title{
Recent Advances in the Understanding of Iron Metabolism and Iron-Related Diseases
}

\author{
A.V. Hoffbrand \\ Royal Free Hospital, London, UK
}

This special issue of Acta Haematologica brings together as authors many of the clinical scientists who have made major contributions to our understanding of iron metabolism and the mechanisms and treatment of ironrelated diseases. It is dedicated to the memory of Prof. Ernest Beutler (1928-2008) who performed outstanding basic and clinical research on iron, as well as in many other areas of medicine (fig. 1).

My own interest in iron metabolism and iron overload began 40 years ago when I was at the Hammersmith Hospital in the Department of Haematology directed by Sir John Dacie. Two brothers with congenital sideroblastic anaemia were under my care. The younger boy needed regular blood transfusions and became iron overloaded. It was his need for effective iron chelation therapy that stimulated studies showing the efficacy of iron removal by subcutaneous desferrioxamine [1]. Pioneered in the USA by Propper et al. [2], this soon became standard chelation therapy for transfusional iron overload. It was shown to improve liver and cardiac function and overall survival in thalassaemia major. Many patients worldwide were still dying, however, from iron overload because the drug was too expensive in poor countries or because patients failed to comply with self-administered infusions on 5 or more days a week. Also, some apparently compliant patients were still developing an iron-induced cardiomyopathy which was difficult to predict from standard measures of body iron, such as serum ferritin or liver

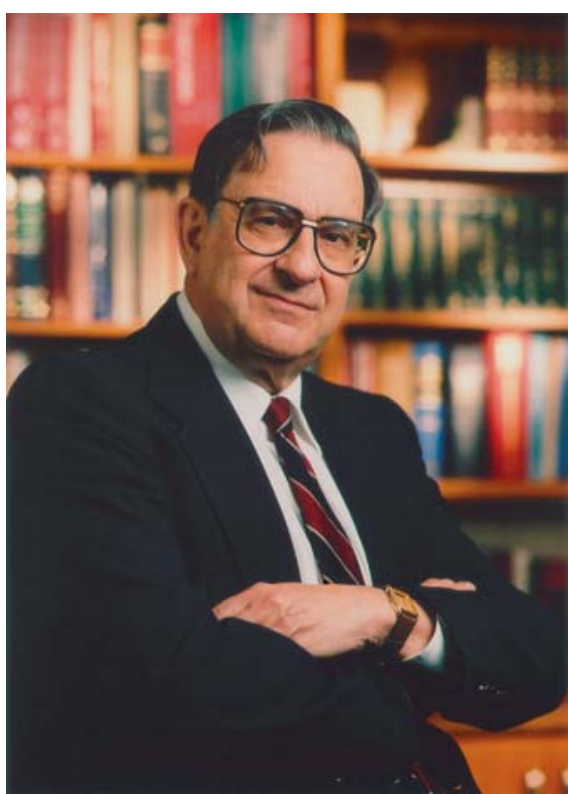

Fig. 1. Prof. Ernest Beutler.

iron. There remained an urgent need for a cheap, orally active iron chelator and for a non-invasive method of measuring cardiac iron.

The first report of an effective orally active iron chelator, deferiprone, appeared in 1987 [3] and this drug is still

\section{KARGER}

Fax +4161306 1234

E-Mail karger@karger.ch

www.karger.com
(C) 2009 S. Karger AG, Basel

0001-5792/09/1223-0075\$26.00/0

Accessible online at:

www.karger.com/aha
Prof. A.V. Hoffbrand Royal Free Hospital Pond Street, London, NW3 2QG (UK)

Tel. +44 207794 0500, ext. 33 258, Fax +44 2074314537

E-Mail v.hoffbrand@ medsch.ucl.ac.uk 
widely used. It appears to be particularly effective at removing cardiac iron. The development of the T2* MRI technique in Prof. Dudley Pennell's Department at the Royal Brompton Hospital in London fulfilled the need for a non-invasive reproducible technique for measuring cardiac iron [4]. It has enabled direct comparison of the efficacy of chelators on cardiac iron and prompted increased chelation for those patients with excess cardiac iron that would not otherwise have been detected [5].

A second orally active chelator, deferasirox, has subsequently been introduced with the advantage of once rather than three times daily administration and appears to be well tolerated [6]. The oral chelators used alone or in combination with desferrioxamine [7] have not only improved survival for thalassaemia major [8] but also made practical, iron chelation therapy for a wide range of other transfusion-dependent refractory anaemias.

Iron deficiency remains the most common anaemia in every country of the world with recent evidence that $\mathrm{He}$ licobacter pylori and atrophic gastritis are common in its aetiology [9]. Simultaneously with these major clinical developments there has been a remarkable increase in the understanding of iron absorption, metabolism and cellular homeostasis by the discovery of a wide range of proteins involved in these processes [10, 11]. Ernest Beutler's laboratory contributed substantially to this new knowledge [12] and his investigations on genetic haemochromatosis have been critical in understanding genotypic/ phenotypic relations in this disease [13]. Research into rare genetic diseases of iron overload and metabolism has helped to identify the proteins involved and elucidate their function $[14,15]$. It has also revealed 'new' diseases such as iron-refractory iron deficiency anaemia [16] and different types of hereditary sideroblastic anaemias [17, 18], and improved our understanding and management of the more common anaemias of chronic inflammation, malignancy and heart failure reviewed in this issue by Agarwal and Prchal and by Silverberg and colleagues.

I first met Ernest Beutler in December 1967 in Toronto (Canada) at the coldest of ASH meetings. His outstanding research in enzyme deficiencies which cause haemolytic anaemia paralleled research of John Dacie at the Hammersmith Hospital. I reestablished contact with him in 1979 when he was President of the ASH meeting in the much warmer climate of Phoenix (Ariz., USA), when I was one of only five British haematologists attending. Since then he remained an intellectually stimulating, helpful and gracious friend to me, as to many other colleagues throughout the world. In 2003, he asked me to take part in an ASH Educational Symposium, despite my advocacy of deferiprone, at a time when this was regarded, in the USA at least, as heretical. When I was first asked last year to edit an 'iron' issue for Acta Haematologica, I immediately invited Ernest Beutler to co-edit this with me. He declined because of illness but following his recent major research in establishing the role of matriptase2 in iron metabolism, I invited him to write on this new topic. Five days before he died, he had the courtesy to suggest his colleague Dr. Pauline Lee might author this article in his place.

Ernest Beutler had a remarkable ability to achieve original, significant research in a wide range of topics, both at the clinical and basic science level. He made great contributions to our understanding of the genetic mechanisms of X-chromosome inactivation, glucose-6-phosphate dehydrogenase deficiency [19], other hereditary haemolytic anaemias, Tay-Sachs and Gaucher's disease [20], galactosaemia, iron metabolism and iron overload. $\mathrm{He}$ combined original scientific research in these and other topics with pioneering clinical research in the fields of haemochromatosis, bone marrow transplantation, the treatment of Gaucher's disease, blood storage, platelet transfusions and the use of new drugs such as chlorodoxyadenosine. In 1983, he introduced the first commercial bibliographic management software package, having written the programme himself. As well as over 800 original scientific papers, he authored 19 books and over 300 chapters. He was a truly outstanding haematologist, recognised by many awards and prizes. In 2007 he was the first recipient of the Wallace $\mathrm{H}$. Coulter Award for Lifetime Achievement in Haematology. His career and the impact of his research on all haematologists have been more fully described by his son, Bruce Beutler [21]. We all miss his incisive intellect, originality, great sense of humour and warm friendship.

\begin{tabular}{|c|c|}
\hline References & $\begin{array}{l}\text { Hussain MA, Green N, Flynn DM, Hussein } \\
\text { S, Hoffbrand AV: Subcutaneous infusion } \\
\text { and intramuscular injection of desferriox- } \\
\text { amine in patients with transfusional iron } \\
\text { overload. Lancet 1976;ii:1278-1280. } \\
2 \text { Propper RD, Cooper B, Rufo RR, Nienhuis } \\
\text { AW, Anderson WF, Bunn HF, Rosenthal A, } \\
\text { Nathan DG: Continuous subcutaneous ad- } \\
\text { ministration of desferrioxamine in patients } \\
\text { with iron overload. N Engl J Med 1977;297: } \\
\text { 418-423. } \\
3 \text { Kontoghiorghes GJ, Aldouri M, Sheppard L, } \\
\text { Hoffbrand AV: 1,2-Dimethyl-3-hydroxy- } \\
\text { pyrid-4-one, an orally active chelator for } \\
\text { treatment of iron overload. Lancet } \\
\text { 1987;i:1294-1295. }\end{array}$ \\
\hline
\end{tabular}

Hoffbrand 
4 Anderson LJ, Holden S, Davis B, Prescott E, Charrier CC, Bunce NH, Firmin DN, Wonke B, Porter J, Walker JM, Pennell DJ: Cardiovascular T2-star $\left(\mathrm{T} 2{ }^{*}\right)$ magnetic resonance for the early diagnosis of myocardial iron overload. Eur Heart J 2001;22:2171-2179.

5 Anderson LJ, Westwood MA, Prescott E, Walker JM, Pennell DJ, Wonke B: Development of thalassemic iron overload cardiomyopathy despite low liver iron levels and meticulous compliance to desferrioxamine. Acta Haematol 2006;115:106-108.

6 Galanello R, Piga A, Alberti D, Rouan MC, Bigler H, Séchaud R: Safety, tolerability, and pharmacokinetics of ICL670, a new orally active iron-chelating agent in patients with transfusion-dependent iron overload due to $\beta$-thalassemia. J Clin Pharmacol 2003;43: 565-572.

7 Wonke B, Wright S, Hoffbrand AV: Combined therapy with deferiprone and desferrioxamine. Br J Haematol 1998; 103:361364.

8 Modell B, Khan M, Darlison M, Westwood MA, Ingram D, Pennell DJ: Improved survival of thalassaemia major in the UK and relation to $\mathrm{T}^{*}$ cardiovascular magnetic resonance. J Cardiovasc Magn Reson 2008; 10: 42.
9 Hershko C, Hoffbrand AV, Keret D, Souroujon M, Maschler I, Monselise Y, Lahad A: Role of autoimmune gastritis, Helicobacter pylori and celiac disease in refractory or unexplained iron deficiency anemia. Haematologica 2005;90:585-595.

10 Nemeth E, Tuttle MS, Powelson J, Vaughn MB, Donovan A, Ward DM, Ganz T, Kaplan J: Hepcidin regulates cellular iron efflux by binding to ferroportin and inducing its internalization. Science 2004;306:2090-2093.

-11 Lee PL, Beutler E: Regulation of hepcidin and iron-overload disease. Annu Rev Pathol 2009;4:489-515.

12 Du X, She E, Gelbart T, Truksa J, Lee P, Xia Y, Khovananth K, Mudd S, Mann N, Moresco EM, Beutler E, Beutler B: The serine protease TMPRSS6 is required to sense iron deficiency. Science 2008;320:1088-1092.

13 Beutler E, Felitti VJ, Koziol JA, Ho NJ, Gelbart T: Penetrance of $845 \mathrm{G} \rightarrow \mathrm{A}(\mathrm{C} 282 \mathrm{Y}) \mathrm{HFE}$ hereditary haemochromatosis mutation in the USA. Lancet 2002;359:211-218.
4 Camaschella C: Understanding iron homeostasis through genetic analysis of hemochromatosis and related disorders. Blood 2005; 106:3710-3717.

15 Zhang AS, Enns CA: Iron homeostasis: recently identified proteins provide insight into novel control mechanisms. J Biol Chem 2009;284:711-715.

16 Iolascon A, De Falco L, Beaumont C: Molecular basis of inherited microcytic anemia due to defects in iron acquisition or heme synthesis. Haematologica 2009;94:395-408.

17 Camaschella C: Recent advances in the understanding of inherited sideroblastic anaemia. Br J Haematol 2008;143:27-38.

18 Napier I, Ponka P, Richardson DR: Iron trafficking in the mitochondrion: novel pathways revealed by disease. Blood 2005; 105 : 1867-1874.

19 Beutler E, Dern RJ, Alving AS: The hemolytic effect of primaquine. III. A study of primaquine-sensitive erythrocytes. J Lab Clin Med 1954;44:177-184.

20 Beutler E: Gaucher disease. Adv Genet 1995; 32:17-49.

21 Beutler B: Obituary: Ernest Beutler (19282008). Haematologica 2009;94:154-156. 